\title{
DAMPAK KESENJANGAN ANTARA PENERIMAAN DAN PENYALURAN DANA ZIS TERHADAP PROGRAM-PROGRAM LAZNAS AL-AZHAR ${ }^{1}$
}

\author{
Dinda Ratnasari \\ Departemen Ekonomi Syariah - Fakultas Ekonomi dan Bisnis - Universitas Airlangga \\ Email: \\ Suherman Rosyidi \\ Departemen Ekonomi Syariah - Fakultas Ekonomi dan Bisnis - Universitas Airlangga \\ Email: srosyidi@gmail.com
}

\begin{abstract}
:
This study's purpose is to find out how LAZNAS Al-Azhar's programs are affected by the gap between the collection and distribution of ZIS funds. The effects of the gap are identified by using the four aspects of zakat institution performance indicators, , which are input, process, output, and quality of the interview questions. This study used a qualitative approach with a case study strategy. Data collection is done through interviews with informants, direct observation, and documentation of the research object. The analytical technique used is qualitative descriptive, namely by narrating and describing the results of interviews and direct observation. The study's results are the impacts arising from the gap between the collection and distribution of ZIS funds to the sustainability of LAZNAS Al-Azhar's programs which is LAZNAS Al-Azhar running large value programs with bailout funds in advance, LAZNAS Al-Azhar carries out routine programs such as assistance programs for orphans with bailout funds in advance as well. Programs in which the funds are collected first before being distributed are assistance programs for affected areas or scholarship programs. LAZNAS Al-Azhar has tried to minimize the gap that has occurred with not to hold the funds collected for too long time. The funds that have been collected will soon be channeled through programs in the community.
\end{abstract}

Keywords: Gap, Zakat, Collection, Distribution, Performance.

\section{PENDAHULUAN}

\section{Latar Belakang}

Rasulullah SAW bersabda bahwa, "Islam itu dibina di atas lima pilar (dasar): Bersaksi, bahwa tiada Tuhan yang patut disembah kecuali Allah, nabi Muhammad adalah utusan-Nya, mendirikan shalat, membayar zakat, puasa ramadhan, dan menunaikan haji ke Baitullah bagi orangorang yang mampu" (HR.Bukhari). Sementara itu, dapat dijumpai pula di dalam Al-Qur'an bahwa sebagian perintah mendirikan shalat selalu diiringi dengan perintah membayar zakat. Salah satu ayat tentang perintah tersebut disebutkan dalam salah satu firman Allah yakni surat Al-Baqarah ayat 43 :

Artinya: dan dirikanlah shalat, tunaikanlah zakat dan ruku'lah beserta orang-orang yang ruku'.Dari sini dapat disimpulkan betapa pentingnya arti zakat bagi seorang muslim.

Baik dalam pengertian agama maupun dipandang dari kepentingan sosial, zakat secara konseptual dapat berperan besar. Kita dapat melihat hal tersebut dalam tiga isu yaitu sebagai salah satu sarana yang dapat

\footnotetext{
${ }^{1}$ Jurnal ini merupakan bagian dari skripsi Dinda Ratnasari, NIM:041311433146, yang diuji pada tanggal 19 Oktober 2018.
} 
Ratnasari, et al: Jurnal Ekonomi Syariah Teori dan Terapan Vol. 6 No. 3 Maret 2019: 489-509; DAMPAK KESENJANGAN ANTARA PENERIMAAN DAN PENYALURAN DANA ZIS TERHADAP PROGRAM-PROGRAM LAZNAS AL-AZHAR

mendekatkan diri kita dengan Allah SWT, salah satu ajaran Islam yang sifatnya wajib bagi setiap muslim yang mampu, dandapat dijadikan penyeimbang kehidupan sosial masyarakat.

Dari sisi pembangunan kesejahteraan umat, zakat merupakan salah satu instrumen pemerataan distribusi pendapatan. Jika zakat dikelola dengan baik dalam hal penerimaan maupun pendistribusian, pasti akan dapat mengangkat kesejahteraan masyarakat. Dengan demikian zakat yang dikelola dengan baik, dimungkinkan membangun pertumbuhan ekonomi sekaligus pemerataan pendapatan, economic with equity. Untuk mewujudkan hal ini sangat diperlukan suatu pembentukan lembaga pengelola zakat yang kompeten untuk menerima, mengelola hingga mendistribusikan dana zis tersebut secara efektif dan efisien agar zis dapat terdistribusi secara merata sesuai sasaran, selain itu sangat diperlukan pula peran masyarakat dan pemerintah guna menunjang kinerja lembaga pengelola zakat.

Berdasarkan peraturan yang ada, masih terdapat peluang yang besar untuk optimalisasi pendistribusian dana ZIS. Akan tetapi, dalam praktek di lapangan, penerapan peraturan tersebut masih jauh dari apa yang diharapkan. Zakat seharusnya didistribusikan secara tepat waktu dan tepat sasaran kepada delapan golongan asnaf. Akan tetapi, sampai saat ini masih terdapat kesenjangan dalam pengumpulan dan pendistribusian zakat di Indonesia. Realita di lapangan memberikan gambaran bahwa masih tedapat ketidakoptimalan dalam pengelolaan zakat. Salah satu contoh yang dapat diambil adalah dari Lembaga Amil Zakat Nasional Al-Azhar. LAZNAS Al-Azhar adalah sebuah organisasi nirlaba yang didirikan serta berada di bawah naungan Yayasan Pesantren Islam (YPI) Al-Azhar.AdapunKinerja keuangan LAZNAS Al-Azhar dapat dilihat pada grafik dibawah ini.

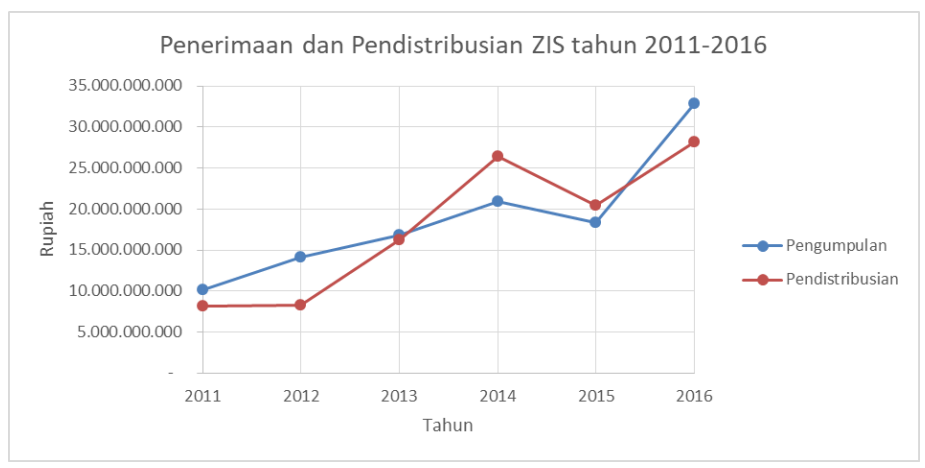

\section{Gambar 1.}

Penerimaan dan Pendistribusian ZIS tahun 2011-2016

Sistem pendistribusian zakat yang baik idealnya dapat menjaga persentase kesenjangan pada nilai yang rendah sepanjang tahun atau dengan trend yang semakin mengecil. Akan tetapi, pencapaian LAZ Al-Azhar bersifat fluktuatif. Hal ini menunjukkan bahwa masih terdapat peluang untuk melakukann optimalisasi pada sistem pendistribusian zakat di LAZ Al-Azhar. Optimalisasi ini dapat dilakukan dengan cara menyelidiki penyebab-penyebab kesenjangan tersebut.

Berdasarkan uraian di atas perlu dilakukan penelitian untuk mengkaji lebih 
Ratnasari, et al: Jurnal Ekonomi Syariah Teori dan Terapan Vol. 6 No. 3 Maret 2019: 489-509; DAMPAK KESENJANGAN ANTARA PENERIMAAN DAN PENYALURAN DANA ZIS TERHADAP PROGRAM-PROGRAM LAZNAS AL-AZHAR

lanjut terkait kesenjangan yang terjadi pada lembaga amil zakat nasional AlAzhar dalam pengelolaan dana zakat. Agar mendapatkan hasil penelitian yang diharapkan maka peneliti perlu menyelidiki apa yang menjadi penyebab dan dampak apa saja yang ditimbulkan akibat terjadinya kesenjangan tersebut. Maka dari itu, penelitian ini megambil objek penelitian LAZ Al-Azhar untuk diteliti penyebab lebih lanjut, sehingga judul penelitian ini adalah "Analisis Kesenjangan Antara Penerimaan Dan Penyaluran Dana ZIS Pada Lembaga Amil Zakat Nasional AlAzhar"

\section{Rumusan Masalah}

Berdasarkan latar belakang masalah yang telah diuraikan diatas, maka permasalahan yang dapat dirumuskan, adalah Bagaimana dampak kesenjangan antara penerimaan dan penyaluran dana ZIS terhadap keberlangsungan program-program pada LAZNAS Al-Azhar?

\section{Tujuan Penelitian}

Tujuan penelitian ini adalah untuk menganalisis dan mengetahui dampak kesenjangan antara penerimaan dan penyaluran dana ZIS terhadap keberlangsungan program-program pada LAZNAS Al-Azhar

\section{LANDASAN TEORI}

Zakat merupakan penyaluran harta dari orang kaya kepada mereka yang berhak menerima. Zakat dapat membersihkan diri, jiwa dan harta dari sifat kikir, iri, bahkan sombong. Zakat adalah harta yang wajib dikeluarkan oleh mereka yang mampu untuk mengeluarkan zakat, serta disalurkan kepada orang-orang yang telah ditentukan pula yaitu delapan golongan yang berhak menerima zakat. Selain itu zakat harus disertai niat sebagaimana ibadah-ibadah lainnya sebagaimana disebutkan pada qs. At-Taubah: 60

Artinya: Sesungguhnya zakat hanyalah untuk orang-orang fakir, orang miskin, amil zakat, yang dilunakkan hatinya (mualaf), untuk (memerdekakan) hamba sahaya, untuk (membebaskan) orang yang berhutang, untuk jalan Allah dan untuk orang yang sedang dalam perjalanan, sebagai kewajiban dari Allah. Allah Maha Mengetahui, Maha Bijaksana. (Departemen Agama RI, 2012)

Zakat tidak secara mutlak diwajibkan atau dibebankan kepada semua manusia.Syarat-syarat zakat yang harus terpenuhi itu meliputi dua aspek penting yaitu syarat untuk muzakki dan syarat harta yang akan dizakati.Al-Zuhayly (2008:98-111) menyebutkan syarat wajib zakat untuk muzakki adalah Merdeka,

Islam, Baligh, dan berakal.Adapun syarat yang harus dipenuhi bagi harta kekayaan yang dimiliki oleh seorang muslim untuk disebut sebagai harta yang wajib dizakati adalah harta yang wajib dizakati berkembang, mencapai nishab, harta yang dizakati adalah milik penuh, kepemilikan harta telah mencapai setahun (haul), harta tersebut bukan merupakan harta hasil hutang, dan harta yang akan dizakati melebihi kebutuhan pokok. 
Selain syarat wajib, pelaksanaan zakat juga harus memenuhi syarat sah. Syarat sah adalah hal-hal yang harus dipenuhi agar pembayaran zakat tersebut sah menurut syariat. Al-Zuhayly (2008) menyebutkan syarat sah pelaksanaan zakat ada dua yaitu niat dan tamlik (memindahkan kepemilikan harta kepada penerimanya).

Zakat dikelompokkan menjadi dua macam jenis, yaitu zakat nafs (jiwa)/fitri dan zakat maal (zakat harta). Zakat fitri hukumnya wajib dikeluarkan oleh setiap muslim laki-laki maupun perempuan yang memiliki persediaan bahan makanan selama lebih dari sehari.Zakat maal atau zakat harta adalah sebagian harta yang harus dikeluarkan oleh muslim apabila harta tersebut telah memenuhi syariat wajib zakat.Zakat maal terbagi menjadi zakat emas dan perak, zakat vang dan surat berharga, zakat perdagangan, zakat pertanian, zakat hewan ternak, zakat barang tambang, serta zakat rikaz.

M.A. Mannan menyebutkan dalam bukunya Islamic Economics: Theory and Practice (Lahore, 1970: 285), zakat memiliki enam prinsip yaitu Prinsip keyakinan keagamaan (faith), Prinsip pemerataan (equity) dan keadilan, Prinsip produktivitas (productivity ) dan kematangan,Prinsip nalar (reason), Prinsip kebebasan (freedom), serta Prinsip etik dan kewajaran (ethic\&proper).

Qardhawi dalam Sudirman (2007:52) menyatakan terdapat dua macam tujuan penting dari ajaran zakat, yaitu tujuan zakat untuk kehidupan individu baik muzakki maupun mustahiq dan tujuan zakat untuk kehidupan sosial kemasyarakatan. Tujuan zakat untuk kehidupan individu dan yang berkaitan dengan muzakki adalah dapat mensucikan jiwa manusia dari sifat kikir dan tamak pada harta, mengobati hati dari cinta dunia, mengembangkan kekayaan batin, menumbuhkan rasa cinta sesama manusia, serta Zakat sebagai mensucikan harta.Tujuan zakat untuk kehidupan individu yang berkaitan dengan Mustahiq adalahmenghilangkan sifat iri dengki dan benci serta membebaskan penerimanya dari tekanan kebutuhan.

$$
\text { Hafidhuddin }
$$
mengemukakan pendapatnya terkait hikmah dan manfaat yang dapat diambil dari berzakat yaitubisa menjadi salah satu sarana untuk menujukkan rasa syukur atas nikmat-Nya, merupakan hak mustahikyang berfungsi menolong dan membantu kearah kehidupan yang lebih baik dan lebih sejahtera,sebagai pilar amal bersama (jamai) antara orangorang kaya yang berkecukupan hidupnya dan para mujahid yang seluruh waktunya digunakan untuk berjihad dijalan Allah, menjadi salah satu sumber dana bagi pembangunan sarana maupun prasarana yang harus dimiliki umat Islam, memasyarakatkan etika bisnis yang benar, merupakan salah satu instrumen pemerataan pendapatan, serta menunjukkan umatnya agar mampu bekerja dan berusaha sehingga memiliki harta kekayaan disamping untuk 
Ratnasari, et al: Jurnal Ekonomi Syariah Teori dan Terapan Vol. 6 No. 3 Maret 2019: 489-509; DAMPAK KESENJANGAN ANTARA PENERIMAAN DAN PENYALURAN DANA ZIS TERHADAP PROGRAM-PROGRAM LAZNAS AL-AZHAR

memnuhi kebutuhan hidupnya adalah untuk berzakat.

infaq adalah harta yang dikeluarkan oleh seseorang atau badan usaha di luar zakat untuk kemaslahatan umum.Infaq berbeda dengan zakat. Infaq tidak mempunyai batasan nishab atau jumlah harta yang ditentukan. Infaq dikeluarkan oleh setiap orang yang beriman, baik yang berpenghasilan tinggi maupun rendah, baik lapang maupun sempit. Jika zakat harus diberikan pada mustahik tertentu (8 asnaf) maka infaq tidak harus diberikan kepada mustahik tertentu, melainkan kepada siapapun misanya orang tua, kerabat, anak yatim, orang miskin, atau orang-orang yang sedang dalam perjalanan.

Sedekah bisa diartikan mengeluarkan harta di jalan Allahsebagai bukti kejujuran atau kebenaran iman seseorang. Menurut terminologi syariat, pengertian shadaqah dan ketentuan hukumnya disamakan dengan infaq.Keterangan mengenai perbedaan zakat dan infaq diatas dapat diringkas dalam bentuk tabel seperti berikut.

Tabel 1.

Perbedaan Zakat, Infaq dan Shadaqah

\begin{tabular}{|c|c|c|c|}
\hline $\begin{array}{c}\text { PERBEDAA } \\
\text { N }\end{array}$ & ZAKAT & $\begin{array}{c}\text { INFA } \\
\mathbf{Q}\end{array}$ & $\begin{array}{c}\text { SHADAQ } \\
\text { AH }\end{array}$ \\
\hline $\begin{array}{c}\text { Kelompom } \\
\text { yang } \\
\text { menerima }\end{array}$ & Wajib & $\begin{array}{c}\text { Sunn } \\
\text { ah }\end{array}$ & Sunnah \\
\hline Batasan & Ada & Tidak & Tidak \\
\hline
\end{tabular}

\begin{tabular}{|c|c|c|c|}
\hline nishab & & ada & ada \\
\hline Waktu & Hanya & & \\
pada & Beba & \\
pelaksana & waktu & Bebas \\
& tertent & & \\
& $u$ & & \\
\hline
\end{tabular}

Menurut Hafidhuddin (2002:125), pengelolaan zakat adalah zakat diambil (dijemput) dari orang-orang yang berkewajiban untuk berzakat (muzakki) kemudian terdapat para pihak petugas ('amilin) yang mengambil, menjemput, menulis, menghitung dan mencatat zakat tersebut lalu disalurkan kepada mereka yang berhak menerimanya (mustahiq).

Di Indonesia saat ini terdapat organisasi atau lembaga pengelola zakat yang diatur dalam Undang-Undang Nomor 23 tahun 2011 tentang Pengelolaan Zakat. Di dalam UndangUndang tersebut terdapat tujuan dan azas pengelolaan zakat yang telah dijelaskan pada pasal 2 (dua) dan 3 (tiga). Pengelolaan zakat bertujuan untuk meningkatkan efektifitas dan efisiensi pelayanan dalam pengelolaan zakat, meningkatkan manfaat zakat untuk mewujudkan kesejahteraan masyarakat dan penanggulangan kemiskinan. Lembaga pengelola zakat di Indonesia terbagi menjadi dua yakni Badan Amil Zakat (BAZ) dan Lembaga Amil Zakat (LAZ). Badan Amil Zakat Nasional (BAZNAS) dibentuk oleh pemerintah dan Lembaga Amil Zakat (LAZ) didirikan oleh masyarakat.Menurut Undang-Undang 23 Tahun 2011 pasal 17, tugas pokok LAZ 
Ratnasari, et al: Jurnal Ekonomi Syariah Teori dan Terapan Vol. 6 No. 3 Maret 2019: 489-509; DAMPAK KESENJANGAN ANTARA PENERIMAAN DAN PENYALURAN DANA ZIS TERHADAP PROGRAM-PROGRAM LAZNAS AL-AZHAR

adalah untuk membantu BAZNAS dalam pelaksanaan pengumpulan, pendistribusian dan pendayagunaan zakat sesuai dengan ketentuan agama.Pendistribusian zakat dapat diartikan sebagai cara penyaluran dana zakat yang diterima dari pihak muzakki kepada para kelompok yang berhak menerima zakat (mustahik). Pendayagunaan zakat adalah bentuk sumber daya yang dimanfaatkan secara maksimum (dana zakat) untuk mencapai kemaslahatan bagi umat sehingga memiliki fungsi sosial dan sekaligus fungsi ekonomi (kosumtif dan produktif). Pendayagunaan diarahkan pada tujuan pemberdayaan melalui berbagai program yang berdampak positif (maslahat) bagi masyarakat khususnya umat islam yang kurang beruntung (delapan asnaf) (Gazi Inayah, 2003:198).

Kesenjangan adalah selisih antara penerimaan dan penyaluran dana zakat. Selisih tersebut dapat berupa selisih nominal penerimaan dan penyaluran maupun selisih waktu antara penerimaan dan penyaluran dana zakat. Agar zakat dapat berfungsi secara optimal untuk kemakmuran umat, kesenjangan antara penerimaan dan penyaluran zakat harus ditekan sekecil mungkin.

Untuk itu semua, dibutuhkan indikator yang akan digunakan dalam mengukur efektivitas minimalisasi kesenjangan tersebut, serta diperlukan manajemen kinerja lembaga pengelolaan zakat yang baik.Ini sesuai dengan pendapat Halim, Nordin dan Zahlan
(2007) dalam Sari $(2012,33)$ yang menyatakan bahwa terdapat indikator yaitu empat aspek penting yang berkaitan dengan kinerja lembaga zakat dalam mengumpulkan dan mendistribusikan zakat. Empat indikator tersebut dijelaskan dalam tabel berikut.

Tabel 2.

Indikator Kinerja Lembaga Zakat

\begin{tabular}{|c|c|c|}
\hline $\begin{array}{l}\text { Dimen } \\
\text { sions }\end{array}$ & Collection & Distribution \\
\hline \multirow[t]{4}{*}{ Input } & $\begin{array}{l}\text { Zakat payers are } \\
\text { aware of their } \\
\text { responsibilities }\end{array}$ & $\begin{array}{l}\text { Recipients are } \\
\text { aware of their } \\
\text { right as asnaf }\end{array}$ \\
\hline & $\begin{array}{l}\text { Office } \\
\text { infrastructure }\end{array}$ & $\begin{array}{l}\text { Office } \\
\text { infrastructure }\end{array}$ \\
\hline & Number of staffs & Number of staffs \\
\hline & $\begin{array}{l}\text { Availibility of } \\
\text { data base system }\end{array}$ & $\begin{array}{l}\text { Availability of } \\
\text { data base system }\end{array}$ \\
\hline \multirow[t]{4}{*}{ Process } & $\begin{array}{l}\text { Avaibility of } \\
\text { annual budget }\end{array}$ & $\begin{array}{l}\text { Availability of } \\
\text { annual budget }\end{array}$ \\
\hline & $\begin{array}{l}\text { Perception on } \\
\text { collection } \\
\text { Procedure }\end{array}$ & $\begin{array}{l}\text { Perception on } \\
\text { distribution } \\
\text { procedure }\end{array}$ \\
\hline & $\begin{array}{l}\text { Perception on } \\
\text { zakat payers }\end{array}$ & $\begin{array}{l}\text { Perception on } \\
\text { recipients }\end{array}$ \\
\hline & $\begin{array}{l}\text { Information and } \\
\text { feedback from } \\
\text { zakat payers }\end{array}$ & $\begin{array}{l}\text { Information and } \\
\text { feedback from } \\
\text { recipients }\end{array}$ \\
\hline \multirow[t]{4}{*}{ Output } & $\begin{array}{l}\text { Are collection } \\
\text { according to } \\
\text { targets }\end{array}$ & $\begin{array}{l}\text { Are grants } \\
\text { sufficient? }\end{array}$ \\
\hline & $\begin{array}{l}\text { Perception on } \\
\text { fund }\end{array}$ & $\begin{array}{l}\text { Perception on } \\
\text { type of grants }\end{array}$ \\
\hline & $\begin{array}{l}\text { Satisfied with } \\
\text { current collection }\end{array}$ & $\begin{array}{l}\text { Percentage of } \\
\text { fund distributed }\end{array}$ \\
\hline & & Satisfied with \\
\hline
\end{tabular}




\begin{tabular}{|c|c|c|}
\hline \multirow[t]{4}{*}{$\begin{array}{c}\text { Dimen } \\
\text { sions }\end{array}$} & Collection & Distribution \\
\hline & & $\begin{array}{l}\text { current } \\
\text { distribution? }\end{array}$ \\
\hline & & $\begin{array}{l}\text { Grant solves } \\
\text { current } \\
\text { problems? }\end{array}$ \\
\hline & & $\begin{array}{l}\text { Number of } \\
\text { recipients } \\
\text { remove from } \\
\text { receiving aids } \\
\text { due to increase } \\
\text { in economic } \\
\text { status asnaf } \\
\text { remove }\end{array}$ \\
\hline \multirow[t]{3}{*}{ Quality } & $\begin{array}{l}\text { Status of } \\
\text { collection }\end{array}$ & $\begin{array}{l}\text { Status of } \\
\text { distribution }\end{array}$ \\
\hline & $\begin{array}{l}\text { Adhering to } \\
\text { Accounting } \\
\text { system }\end{array}$ & $\begin{array}{l}\text { Adhering to } \\
\text { accounting } \\
\text { system }\end{array}$ \\
\hline & $\begin{array}{l}\text { Availability of } \\
\text { independent } \\
\text { audit }\end{array}$ & $\begin{array}{l}\text { Availibility of } \\
\text { independent } \\
\text { audit }\end{array}$ \\
\hline
\end{tabular}

\section{METODE PENELITIAN}

Pendekatan yang digunakan dalam penelitian ini adalah pedekatan kualitatif dengan metode studi kasus deskriptif. Bodgan dan Taylor mendefinisikan penelitian kualitatif sebagai penelitian yang menghasilkan data deskriptif berupa kata-kata tertulis, atau lisan dari orangorang dan perilaku yang dapat diamati (Moleong, 2001). Tujan utama penelitian ini lebih menjelaskan perilaku daripada menggambarkan dan merumuskannya dalam angka.
Adapun alasan penggunaan pendekatan kualitatif dalam penelitian ini adalah karena data yang dihasilkan berupa data deskriptif yang diperoleh dari data-data berupa tulisan, wawancara, dan dokumen-dokumen terkait. Selain itu, penggunaan metode kualitatif juga digunakan untuk menjawab rumusan masalah penelitian, yaitu "Bagaimana dampak kesenjangan antara penerimaan dan penyaluran dana ZIS terhadap keberlangsungan program-program pada LAZNAS Al-Azhar?". Unit analisis dalam penelitian ini adalahanalisis kesenjangan antara penerimaan dan penyaluran dana zis pada LAZNAS Al-Azhar. Jenis dan sumber data dalam penelitian ini adalah data primer yang berasal dari observasi langsung dan yang dilakukan dengan wawancara secara mendalam kepada branch manager dan divisi fundkompart di dalam lembaga tersebut yang memiliki pemahaman cukup baik tentang kinerja dan perkembangan LAZNAS Al-Azhar. Wawancara tidak hanya dilakukan terhadap kedua informan pihak LAZNAS Al-Azhar saja tetapi wawancara juga dilakukan terhadap dua informan muzakki dan dua informan mustahiq yang telah terdaftar secara resmi di LAZNAS Al-Azhar.

Data sekunder adalah data yang diperoleh secara tidak langsung. Data sekunder adalah data yang diperoleh tidak langsung oleh peneliti dari obyek penelitian. Sumber data sekunder dalam penenitian ini berupa data tertulis yaitu data yang berasal dari hasil penelitian sebelumnya dan literatur-literatur lainnya 
Ratnasari, et al: Jurnal Ekonomi Syariah Teori dan Terapan Vol. 6 No. 3 Maret 2019: 489-509; DAMPAK KESENJANGAN ANTARA PENERIMAAN DAN PENYALURAN DANA ZIS TERHADAP PROGRAM-PROGRAM LAZNAS AL-AZHAR

seperti brosur, buku, majalah, jurnal, surat kabar, artikel online catatan dan dokumen atau laporan kegiatan penelitian lainnya yang memiliki hubungan terkait dengan kesenjangan antara penerimaan dan penyaluran dana zis pada LAZNAS Al-Azhar.

Teknik pengumpulan data yang digunakan dalam penelitian ini dimulai dari wawancarasecara langsung kepada beberapa informan yaitu staff atau pengurus LAZNAS Al-Azhar, mustahik dan muzakki.Pihak-pihak terkait yang akan diwawancarai penulis untuk menjadi informan dalam penelitian ini yaitu sebagai Branch ManagerLAZNAS Al-Azhar, Divisi Fundkompart LAZNAS Al-Azhar, dua orang mustahiq, dan dua orang muzakki. Selanjutnya dilakukan kunjungan lokasi observasi secara langsung di LAZNAS AlAzhar untuk mengamati bagaimana proses penerimaan dan penyaluran dana zis di lembaga tersebut, struktur organisasi lembaga, serta pengelolaan manajemen dana zis nya. Selain itu, akan diamati juga situasi dan kondisi lembaga tersebut.Tahapan berikutnya adalah dokumentasi.Tahapan ini dilakukan untuk memperoleh data pendukung, yaitu catatan-catatan penting, arsip, surat kabar dan sebagainya yang berkaitan dengan pengelolaan, penerimaan dan penyaluran dana zis di LAZNAS Al-Azhar.

Teknik validasi yang digunakan dalam penelitian ini adalah triangulasi sumber data, yaitu membandingkan dan mengecek sumber yang didapat dari hasil wawancara dengan dua informan pihak
LAZNAS Al-Azhar, dua informan muzakki dan dua informan mustahik. Tiga teknik dalam analisis data di lapangan model Miles dan Huberman, yaitu:

1. Reduksi Data.

Data yang diperoleh melalui wawancara di lapangan harus segera diolah, karena jumlahnya yang tidak sedikit. Kemudian hasil rekaman wawancara tersebut diransformasi dalam bentuk transkip, wawancara tertulis, observasi, dan dokumenasi. Pada, tahap selanjutnya peneliti melakukan seleksi terhadap data yang akan disajikan di dalam hasil penelitian, dengan maksud data yang akan disajikan hanyalah data yang dibutuhkan dalam penelitian untuk memudahkan proses analisis.

2. Penyajian Data

Data disajikan dalam bemtuk teks naratif agar lebih mudah dipahami. Disisi lain data yang disajikan tidak selalu dalam bentuk teks naratif, Sugiyono $(2015,249)$ menjelaskan bahwa, "dalam penelitian kualitatif penyajian data bisa dilakukan dalam bentuk uraian singkat, bagan, hubungan antar kategori, flowchart, dan sejenisnya". Bentuk teks naratif yang disajikan berupa data berisikan hasil wawancara dengan informan pihak LAZNAS AlAzhar, informan muzakki dan informan mustahik

3. Menarik Kesimpulan 
Ratnasari, et al: Jurnal Ekonomi Syariah Teori dan Terapan Vol. 6 No. 3 Maret 2019: 489-509; DAMPAK KESENJANGAN ANTARA PENERIMAAN DAN PENYALURAN DANA ZIS TERHADAP PROGRAM-PROGRAM LAZNAS AL-AZHAR

Tahap yang terakhir adalah menarik kesimpulan. Penarikan kesimpulan berupa kegiatan interpretasi, yaitu menemukan makna data yang telah disajikan. Selanjutnya data dianalisis dalam bentuk kata-kata untuk mendiskripsikan fakta yang ada di lapangan atau untuk menjawab rumusan masalah penelitian ini tentang studi kasus pada pihak LAZNAS Al-Azhar.

\section{HASIL DAN PEMBAHASAN}

Berikut ini akan disampaikan hasil analisis penelitian selama melakukan proses penelitian yaitu meliputi tentang hasil analisis berdasarkan empat indikator zakat performance terhadap penghimpunan, empat indikator zakat performance terhadap penyaluran dan hasil analisis data laporan keuangan kesenjangan, penyebab, dampak terhadap LAZNAS Al-Azhar.

\section{Indicator Zakat performance terhadap Penghimpunan.}

Seperti yang sudah diketahui, terdapat empat indikator yang harus diamati untuk dapat menilai zakat performance terhadap penghimpunan. Keempat indikator tersebut akan dijelaskan hasil analisisnya sebagai berikut:

1. Indikator Input.

Indikator input terdiri dari empat faktor atau unsur penentu. Yang pertama adalah faktor yang mempengaruhi pengumpulan zakat, yakni para pembayar zakat sadar akan kewajibannya sebagai muzakki.
Pada LAZNAS Al-Azhar, terdapat dua golongan muzakki terkait indikator ini. Golongan pertama adalah golongan yang paham tentang zakat beserta nisab dan haulnya sedangkan golongan kedua adalah orang-orang yang menunaikan zakat dengan jumlah sesuka hatinya tanpa mengikuti ketentuan nisab dan haul. Oleh karena itu, dapat disimpulkan bahwa tingkat kesadaran muzakki untuk berzakat sudah ada tetapi masih perlu ditingkatkan kembali untuk meningkatkan jumlah penghimpunan dana ZIS LAZNAS Al-Azhar. Peningkatan tersebut dapat dilakukan dengan cara mengintensifkan edukasi dan pemahaman tentang zakat dari al-azhar ke musakki. Hal ini sejalan dengan hasil penelitian sari (2012) bahwa kesadaran para muzakki untuk membayar zakat saat ini sudah lebih baik dari tahun-tahun sebelumnya.

Faktor berikutnya yang mempengaruhi penghimpunan zakat adalah infrastruktur perkantoran. Sarana infrastruktur perkantoran di LAZNAS Al-Azhar Jawa Timur saat ini dirasa cukup oleh pengurus, walaupun saat ini gedung kantor yang mereka tempati masih berstatus kontrak dengan menggunakan dana operasional. Faktor selanjutnya yang mempengaruhi penghimpunan zakat adalah jumlah pegawai badan amil. Pihak pengurus LAZNAS Al-Azhar Jawa Timur merasa kurang cukup dengan jumlah pegawai amil yang hanya 
Ratnasari, et al: Jurnal Ekonomi Syariah Teori dan Terapan Vol. 6 No. 3 Maret 2019: 489-509; DAMPAK KESENJANGAN ANTARA PENERIMAAN DAN PENYALURAN DANA ZIS TERHADAP PROGRAM-PROGRAM LAZNAS AL-AZHAR

tujuh orang sedangkan di pusat terdapat 120 amil. Selain pegawai amil, biasanya LAZNAS Al-Azhar merekrut relawan untuk ikut mensyiarkan program LAZNAS Al-Azhar. Terkait dengan kondisi kedua faktor tersebut, sosialisasi program-program LAZNAS Al-Azhar masih dapat dilakukan baik secara internal seperti ke lembaga pendidikan LAZNAS AlAzhar maupun secara eksternal dengan cara bekerja sama dengan pihak akademisi, bisnis, society, dan government. Dengan demikian, dapat disimpulkan masih terdapat peluang untuk meningkatkan sarana dan jumlah amil dengan tetap mempertimbangkan pertambahan dana operasional, agar peningkatan tersebut disertai dengan peningkatan jumlah pengumpulan zakat yang optimal untuk disalurkan ke mustahik. Hal ini sejalan dengan hasil penelitian sari (2012) bahwa sarana, prasarana, dan jumlah pegawai badan amil masih kurang cukup untuk menjalankan operasioanal badan amil.

Faktor terakhir adalah keberadaan database muzakki. Sistem yang digunakan oleh LAZNAS Al-Azhar saat ini sudah dapat memuat identitas diri dan kontak yang dapat dihubungi berupa nomor telepon, alamat rumah, atau alamat email, jumlah dana yang disalurkan, serta waktu muzakki tersebut menunaikan zakat. Database tersebut sudah dapat memudahkan
LAZNAS Al-Azhar dalam men-syiarkan program-program dan meningkatkan pengumpulan dana ZIS. Pada penelitian sari (2012), tidak dijelaskan secara khusus terkait faktor ini.

2. Indikator Proses.

Indikator proses mencakup empat faktor. Faktor pertama adalah ketersediaan anggaran tahunan. Proses perencanaan anggaran tahunan sudah dilakukan dengan evaluasi yang baik, pertimbangan tentang program rutin atau insidentil, dan alokasi pengeluaran sesuai ketentuan syariah. Hal ini berbeda dengan hasil penelitian sari (2012) yang menyatakan bahwa keterbatasan kewenangan cabang badan amil mempengaruhi efektivitas pengumpulan dan pedistribusian zakat. Faktor kedua adalah prosedur pengumpulan zakat. LAZNAS Al-Azhar telah mensyiarkan seruan berzakat kepada para muzakki dengan berbagai macam program-program distribusi unggulan. Ketertarikan muzakki yang pernah menjadi mustahik di program LAZNAS Al-Azhar untuk berzakat melalui LAZNAS AlAzhar adalah karena sudah pernah merasakan secara langsung manfaat dana zakat tersebut. Selain itu, LAZNAS Al-Azhar telah menyiapkan berbagai metode untuk memudahkan muzakki dalam menunaikan zakatnya. Hal ini sejalan dengan hasil penelitian Sari (2012) yang menyatakan bahwa badan amil menggunakan berbagai 
Ratnasari, et al: Jurnal Ekonomi Syariah Teori dan Terapan Vol. 6 No. 3 Maret 2019: 489-509; DAMPAK KESENJANGAN ANTARA PENERIMAAN DAN PENYALURAN DANA ZIS TERHADAP PROGRAM-PROGRAM LAZNAS AL-AZHAR

media untuk melakukan sosialisasi tentang badan amil dan menyediakan kemudahankemudahan bagi muzakki seperti atm transfer, penjemputan dana, dan konsultasi zakat gratis. Faktor ketiga adalah tentang kriteria pembayar zakat. LAZNAS Al-Azhar sudah membuka pintu untuk mengedukasi kepada muzakki agar menunaikan zakat sesuai kriteria nisab dan haul, akan tetapi tidak semua muzakki mau untuk mendapat edukasi tersebut. Hal ini dapat memperngaruhi jumlah penerimaan dana ZIS LAZNAS Al-Azhar. Pada penelitian Sari (2012), tidak dijelaskan secara khusus terkait faktor ini.

Faktor yang terakhir adalah umpan balik (feedback) dari pembayar zakat. Terdapat beberapa donatur rutin LAZNAS Al-Azhar yang senang ketika diberi reminder untuk berzakat, tetapi terdapat pula yang merasa sebaliknya. Dirasa perlu peningkatan pelayanan muzakki terutama tentang penerbitan bukti pembayaran yang terkadang kurang tepat waktu. Adapun para muzakki sudah merasa dimudahkan untuk menyalurkan ZIS melalui LAZNAS AIAzhar serta banyak mengetahui program-program, laporan keuangan, dan prestasi yang sudah dicapai oleh LAZNAS Al-Azhar. Para Muzakki mendapatkan informasi tersebut dari majalah LAZNAS Al-Azhar. Muzakki LAZNAS Al-Azhar merasa yakin zakat yang mereka tunaikan di LAZNAS AIAzhar akan disalurkan kepada pihak yang tepat. Saran yang didapat dari para muzakki untuk LAZNAS AL-Azhar adalah agar sosialisasi program yang ada pada LAZNAS Al-Azhar lebih ditingkatkan lagi secara terusmenerus, terutama ketika mendekati momen tertentu seperti Idul Adha dan Idul Fitri. Hal ini sejalan dengan hasil penelitian Sari (2012) bahwa para muzakki rajin memberikan feedback melalui berbagai media kepada badan amil. Oleh karena itu dapat disimpulkan masih terdapat beberapa peluang untuk meningkatkan jumlah penerimaan zakat dengan cara melakukan optimalisasi pada indikator proses.

3. Indikator Output.

Indikator ketiga adalah indikator output, yang mencakup tiga faktor penentu, yaitu perbandingan antara realisasi pengumpulan dengan target penerimaan zakat, kriteria jenis paket pengumpulan zakat, dan kepuasan akan realisasi pengumpulan zakat. Pada tahun 2017, LAZNAS Al-Azhar baru dapat mengumpulkan dana Rp 31.000.000.000 dari target $\mathrm{Rp}$ 50.000.000.000, sesuai prasyarat BAZNAS. LAZNAS Al-Azhar perwakilan Jawa Timur sudah cukup puas karena 80-90\% muzakki di LAZNAS Al-Azhar adalah donatur repeat, yaitu doantur yang berdonasi secara rutin di LAZNAS Al-Azhar setiap tahunnya. Pengukuran pada indikator output mencerminkan 
hasil yang dicapai setelah melakukan optimalisasi pada indikator input dan proses. Hal ini sejalan dengan hasil penelitian Sari (2012) pada lembaga amil berbeda bahwa jumlah dana yang terkumpul sudah mencapai target pada setiap tahun.

4. Indikator Quality.

Faktor yang mempengaruhi indikator keempat, yaitu quality, adalah status dana penghimpunan, ketersediaan sistem akuntansi dalam pengelolaan dana zakat, dan ketersediaan lembaga audit independen dalam melakukan audit terhadap laporan tahunan. Faktor pertama adalah status dana penghimpunan. Status dana yang terkumpul di LAZNAS Al-Azhar adalah mayoritas berasal dari muzakki berprofesi sebagai pegawai swasta. Muzakki yang berprofesi sebagai pegawai swasta mendominasi jumlah muzakki di LAZNAS Al-Azhar karena terdapat kerjasama atau MOU antara LAZNAS Al-Azhar dan perusahaan swasta tersebut. Pada penelitian Sari (2012), tidak dijelaskan secara khusus terkait faktor ini.

Faktor kedua, yaitu pengelolaan dana zakat, memerlukan sistem akuntansi. Hal ini menjadi bukti akuntabilitas lembaga tersebut dan merupakan kewajiban setiap lembaga amil zakat untuk kepada muzakki, BAZNAS, dan pemerintah. Oleh karena itu LAZNAS Al-Azhar menerapkan prinsip TRUST dalam pengelolaan zakat. T adalah tertib administrasi, $R$ adalah ramah dalam melayani, $U$ adalah unggul dalam pendayagunaan, $S$ adalah sehat dalam keuangan, T adalah terpercaya dalam pengelolaan. Dengan kelemahan dan keterbatasan sistem hal ini berbeda dengan hasil penelitian Sari (2012) pada lembaga amil berbeda bahwa sistem akuntansi ini yang digunakan adalah metode tunggal dan belum terkomputersasi, sehingga pengambilan keputusan dan pertimbangan yang dilakukan setiap evaluasi untuk perbaikan kinerja juga menjadi kurang optimal.

Sebagaimana faktor ketiga adalah ketersediaan lembaga audit independen dalam melakukan audit terhadap laporan tahunan. Laporan keuangan LAZNAS Al-Azhar diaudit oleh lima lembaga yaitu audit oleh Kantor Akuntan Publik (KAP), audit internal oleh YPI Al-Azhar, audit dari BAZNAS dan Kemenag, audit kepatuhan dan kajian dampak, dan audit sisi syariah untuk mengetahuai kesesuaian pengelolaan Al-Azhar dengan kaidah syariah. Hal ini berbeda dengan hasil penelitian permata Sari (2012) pada lembaga amil berbeda bahwa bentuk transparansi yang dilakukan adalah audit oleh akuntan publik dan laporan rutin dari badan amil pusat.

Indikator Zakat performance terhadap Penyaluran. 
Seperti yang sudah diketahui, terdapat empat indikator yang harus diamati untuk dapat menilai zakat performance terhadap penyaluran. Keempat indikator tersebut akan dijelaskan hasil analisis nya sebagai berikut:

1. Indikator Input.

$\begin{array}{ccc}\text { Faktor } & \text { pertama } & \text { yang } \\ \text { mempengaruhi } & \text { adalah } & \text { para }\end{array}$
penerima sadar akan haknya sebagai mustahik. Di LAZNAS Al-Azhar terdapat beberapa orang yang masuk ke kategori mustahik tetapi tidak mengajukan diri sebagai mustahik. Akan tetapi, terdapat pula orangorang yang mengajukan diri ke LAZNAS Al-Azhar untuk menjadi mustahik dengan cara mengaku kalau dia tidak mampu. Mengingat hal tersebut, assesment penting untuk dilakukan dalam rangka validasi kondisi calon mustahik. Sebagian besar mustahik tidak mengerti tentang zakat. Adapun cara untuk menyadarkan mustahik bisa dilakukan dengan cara melibatkan mereka di dalam program-program pemberdayaan LAZNAS Al-Azhar. Persoalan ini belum pernah disebutsebut oleh muzakki maupun mustahik, sebagaimana terlihat dalam tabel 4.2 meski demikian amil menyebutnya. Pemberdayaan tersebut disertai juga dengan pendampingan. Pendampingan tersebut meliputi dampak dana tersebut terhadap kehidupan mereka sehingga diharapkan ketika sudah mampu kesadaran mereka untuk berzakat akan tinggi. Oleh karena itu, dapat disimpulkan bahwa masih banyak upaya yang perlu dilakukan untuk menjaring mustahik dan mengedukasi tentang zakat agar penyaluran zakat dapat optimal. Hal ini sejalan dengan hasil penelitian Sari (2012) pada lembaga amil berbeda bahwa mayoritas golongan 8 asnaf hanya sedikit memiliki pengetahuan tentang hak-nya tersebut.

Faktor kedua yang mempengaruhi penyaluran zakat adalah infrastruktur perkantoran dan faktor yang ketiga yaitu jumlah pegawai badan amil. Sebagaimana yang sudah dijelaskan sebelumnya terkait kedua faktor tersebut, masih terdapat peluang untuk peningkatan sarana dan jumlah amil agar peningkatan jumlah pengumpulan zakat menjadi optimal. Hal ini sejalan dengan hasil penelitian Sari (2012) bahwa sarana, prasarana, dan jumlah pegawai badan amil masih kurang cukup untuk menjalankan operasioanal badan amil. Faktor keempat adalah keberadaan database mustahik. Database mustahik diperoleh pada saat assessment seperti yang telah disebutkan dengan lebih rinci di dalam sub bab yang baru lalu. Database tersebut memudahkan LAZNAS Al-Azhar dalam memantau history bantuan, perkembangan tingkat kesejahteraan mustahik, dan 
program pemberdayaan yang tepat untuk diikusi oleh mustahik. Pada penelitian Sari (2012), tidak dijelaskan secara khusus terkait faktor ini.

2. Indikator Proses.

Terdapat beberapa faktor yang mempengaruhi indikator proses yaitu prosedur pendistribusian zakat, kriteria penerima zakat, dan umpan balik (feedback) dari penerima zakat. Faktor pertama yakni prosedur pendistribusian zakat. LAZNAS Al-Azhar mendistribusikan dana ZIS dalam bentuk program-program seperti Rumah Gemilang Indonesia (RGI). Mustahik yang ingin mengikuti program-program tersebut harus melalui tahapan assessment terlebih dahulu baru kemudian dapat bergabung. Terdapat pula programprogram lainnya seperti Indonesia Gemilang, My Heart From Yatim, dan Infralink Sejuta Berdaya. Hal ini sejalan dengan hasil penelitian Sari (2012) pada badan amil yang berbeda bahwa prosedur penyaluran yang digunakan adalah melalui programprogram pemberdayaan. Adapun faktor kedua terkait kriteria penerima zakat, LAZNAS Al-Azhar dapat memastikan bahwa dana yang sudah disalurkan akan diterima oleh golongan delapan asnaf karena sudah melalui assessment. Hal ini sejalan dengan hasil penelitian Sari (2012) dan Indriyanti (2016) pada badan amil yang berbeda bahwa penentuan pihak-pihak penerima zakat sudah melalui assessment oleh badan amil tersebut. Selanjutnya faktor ketiga terkait umpan balik (feedback) dari mustahik, selama ini belum ada kritik terhadap LAZNAS AIAzhar. Hal ini sejalan dengan hasil penelitian Sari (2012) pada badan amil yang berbeda bahwa prosedur pendistribusian badan amil tersebut telah mengalami perkembangan dan semakin banyak program yang kreatif serta menarik.

3. Indikator Output.

Faktor-faktor yang mempengaruhi indikator output adalah kriteria jenis paket distribusi zakat, persentase jumlah zakat yang terdistribusi, kepuasan akan realisasi jumlah zakat yang terdistribusi, peran paket distribusi zakat dalam menyelesaikan masalah mustahik atau meningkatkan taraf hidup mustahik dan jumlah mustahik yang keluar dari kriteria mustahik setelah menerima paket distribusi zakat. Faktor tentang kriteria jenis paket distribusi zakat LAZNAS Al-Azhar adalah program-program yang tidak hanya sebagai program pemberdayaan dan charity/karitatif saja namun juga memiliki tujuan untuk pengentasan. Oleh karena itu para mustahik LAZNAS Al-Azhar menyambut dengan antusias program-program tersebut. Mulai tahun 2017, LAZNAS AlAzhar akan melaporkan jumlah mustahik yang teridentifikasi, jumlah yang terbantu, dan jumlah yang terentaskan. Terentaskan dapat 
Ratnasari, et al: Jurnal Ekonomi Syariah Teori dan Terapan Vol. 6 No. 3 Maret 2019: 489-509; DAMPAK KESENJANGAN ANTARA PENERIMAAN DAN PENYALURAN DANA ZIS TERHADAP PROGRAM-PROGRAM LAZNAS AL-AZHAR

didefinisikan sebagai perpindahan status mustahik menjadi orang yang mampu untuk berzakat. Hal ini sejalan dengan penelitian Indriyanti (2016) pada badan amil lain bahwa zakat disalurkan melalui program produktif dan telah mampu mengentaskan sebagian penerima donatur

Faktor selanjutnya mengenai kepuasan akan realisasi zakat yang terdistribusi yakni realisasi program pendistirbusian dan pemberdayaan LAZNAS Al-Azhar sudah cukup puas sesuai dengan sasaran dan harapan. Mengenai faktor presentase jumlah zakat yang terdistribusi, dapat dilaporkan bahwa persentase jumlah dana yang terdistribusi dijaga oleh LAZNAS Al-Azhar agar tidak memiliki selisih terlalu jauh dengan pemasukan. LAZNAS Al-Azhar memiliki kebijakan untuk tidak menahan dana yang terkumpul terlalu lama. Dana yang sudah terkumpul tersebut akan segera disalurkan melalui program-program di masyarakat. Hal ini berbeda dengan hasil penelitian Sari (2012) pada lembaga amil yang berbeda bahwa terdapat beberapa kendala yang masih menghambat pendistribusian dana zakat secara maksimal seperti kebijakan anggaran. Selanjutnya faktor terakhir adalah peran paket distribusi zakat dalam menyelesaikan masalah mustahik atau meningkatkan taraf hidup mustahik dan jumlah mustahik yang keluar dari kriteria mustahik setelah menerima paket distribusi zakat. Mengenai faktor tersebut bahwa LAZNAS Al-Azhar telah menjalankan beberapa program yang sesuai untuk meningkatkan taraf hidup mustahik. Detail program dan pencapaian sudah dapat dipantau di majalah rutin LAZNAS Al-Azhar. Pada majalah tersebut telah dimuat jumlah mustahik yang terentaskan. Hal ini sejalan dengan hasil penelitian Sari (2012) pada badan amil yang berbeda bahwa telah terdapat beberapa orang yang merasa terbantu kehidupannya, tumbuh jiwa mandiri, sehat, serta berpendidikan. Selain itu terdapat pula beberapa orang yang sudah berubah status dari mustahik menjadi muzakki

4. Indikator Quality.

Faktor yang berpengaruh terhadap indikator quality penyaluran adalah sama dengan indikator quality pada penghimpunan yaitu status dana pengumpulan, ketersediaan sistem akuntansi dalam pengelolaan dana zakat dengan menerapkan prinsip TRUST (T adalah tertib administrasi, $R$ adalah ramah dalam melayani, $U$ adalah unggul dalam pendayagunaan, $S$ adalah sehat dalam keuangan, T adalah terpercaya dalam pengelolaan), dan ketersediaan lembaga audit independen dalam melakukan audit terhadap laporan tahunan. Laporan keuangan LAZNAS Al-Azhar diaudit oleh lima lembaga yaitu audit oleh Kantor Akuntan Publik (KAP), audit 
Ratnasari, et al: Jurnal Ekonomi Syariah Teori dan Terapan Vol. 6 No. 3 Maret 2019: 489-509; DAMPAK KESENJANGAN ANTARA PENERIMAAN DAN PENYALURAN DANA ZIS TERHADAP PROGRAM-PROGRAM LAZNAS AL-AZHAR

internal oleh YPI Al-Azhar, audit dari BAZNAS dan Kemenag, audit kepatuhan dan kajian dampak, dan audit sisi syariah untuk mengetahuai kesesuaian pengelolaan Al-Azhar dengan kaidah syariah.

Analisis data laporan keuangan, kesenjangan, penyebab kesenjangan, dan dampaknya terhadap LAZNAS AI-

Azhar.

Keterangan di bawah ini dibuat berdasarkan grafik kinerja kevangan AlAzhar tahun 2011-2016. Dari grafik tersebut dapat diketahui beberapa hal penting dalam hubungannya dengan laporan kevangan, kesenjangan serta penyebab dan dampaknya terhadap LAZNAS AlAzhar.

1. Tidak selalu dana yang terhimpun dapat disalurkan pada tahun yang sama.

2. Kenaikan penerimaan dan penyaluran zakat pada tahun 2011-2016 tidak lepas dari peran LAZNAS Al-Azhar dalam mengevaluasi keberjalanan pengelolaan zakat. Evaluasi tersebut dilakukan dengan cara menganalisa dari segi muzakki, mustahik, program, dan penggunaan media-media komunikasi.

3. Selisih atau kesenjangan yang bernilai negatif antara penerimaan dan penyaluran zakat dapat terjadi. Penyebab dari kesenjangan tersebut adalah:

a. Beberapa perusahaan yang berkomitmen untuk memberi donasi mencairkan dananya tidak pada tahun yang sama

b. Beberapa perusahaan mencairkan dananya pada saat program sudah berjalan selama periode waktu tertentu dan setelah mendapat laporan progress program

c. LAZNAS Al-Azhar telah bergerak untuk melaksanakan program pada tahun yang sama dengan komitmen perusahaan tersebut

d. LAZNAS Al-Azhar menjalankan program-program yang bersifat multi years atau jangka panjang. Program-program tersebut direncanakan, dilaksanakan, dilaporkan, serta menerima dana dari donatur tidak pada periode satu tahun.

e. Mekanisme dan kecepatan penyusunan pelaporan juga berpengaruh karena dana yang tercatat sebagai penerimaan adalah dana yang sudah masuk ke rekening LAZNAS Al-Azhar sedangkan dana yang tercatat sebagai pendistribusian adalah dana yang terlaporkan.

4. Dampak yang ditimbulkan oleh kesenjangan ini adalah :

a. LAZNAS Al-Azhar menjalankan program-program pemberdayaan bernilai besar dengan dana talangan terlebih dahulu. Adapun dana yang masuk diterima secara termin setelah terdapat laporan pelaksanaan program dalam 
Ratnasari, et al: Jurnal Ekonomi Syariah Teori dan Terapan Vol. 6 No. 3 Maret 2019: 489-509; DAMPAK KESENJANGAN ANTARA PENERIMAAN DAN PENYALURAN DANA ZIS TERHADAP PROGRAM-PROGRAM LAZNAS AL-AZHAR

triwulan pertama, triwulan kedua, dan seterusnya ataupun bisa pula terbayar di akhir setelah program tersebut selesai terlaksana.

b. LAZNAS Al-Azhar juga melaksanakan program rutin seperti program bantuan untuk anak yatim dengan dana talangan terlebih dahulu juga. Adapun dana yang masuk dari perusahaan biasanya dilakukan satu bulan atau dua bulan setelah komitmen tersebut mereka nyatakan. Lebih cepat dibandingkan donasi untuk program pemberdayaan besar

c. Program yang dananya terkumpul terlebih dahulu sebelum disalurkan adalah program bantuan terhadap daerah terdampak bencana atau program beasiswa. Aliran dana pada kedua program tersebut berlangsung secara lebih cepat sehingga dana yang masuk biasanya segera disalurkan ke yang membutuhkan.

Kesenjangan yang terjadi telah berusaha untuk diminimalkan oleh LAZNAS Al-Azhar dengan kebijakan untuk tidak menahan dana yang terkumpul terlalu lama. Dana yang sudah terkumpul tersebut akan segera disalurkan melalui program-program di masyarakat. Mengenai kesenjangan yang bernilai negatif, kebijakan dari LAZNAS Al-Azhar pusat adalah memberikan support dalam bentuk dana talangan agar program tersebut dapat berjalan sebelum dana dari donatur masuk ke rekening LAZNAS
Al-Azhar. Sejalan dengan hal itu, LAZNAS Al-Azhar sudah merencanakan agar pendanaan program menggunakan dana dari berbagai sumber yaitu zakat, sponsorship, infaq, sedekah, wakaf, CSR, dan kas LAZNAS Al-Azhar. Jika jumlah pemasukan dari dana CSR berkurang, LAZNAS AL-Azhar mengoptimalkan sumber dana lainnya. Jika dana CSR dari suatu perusahaan telah berhenti, LAZNAS AlAzhar akan mencari perusahaan lainnya untuk menyalurkan dana CSR melalui LAZNAS Al-Azhar. Oleh karena itu, dapat disimpulkan bahwa, LAZNAS Al-Azhar telah berusaha untuk memberikan hasil yang terbaik kepada mustahik dan tidak mengecewakan muzakki yang telah mempercayai LAZNAS Al-Azhar sebagai lembaga amil dalam melakukan pengelolaan dana ZIS, terlepas dari faktorfaktor yang kurang mendukung serta kesenjangan yang timbul dalam pengelolaan dana ZIS tersebut.

\section{SIMPULAN}

1. Berdasarkan indikator input pada zakat performace indicator, LAZNAS Al-Azhar :

a. Memenuhi pada faktor infrastruktur perkantoran dan keberadaan database muzakki dan mustahik

b. tidak memenuhi pada faktor kesadaran muzakki terhadap kewajiban berzakat, kesadaran mustahik akan haknya sebagai penerima zakat, dan jumlah SDM 
2. Berdasarkan indikator proses pada zakat performace indicator, LAZNAS Al-Azhar :

a. Memenuhi

pada

ketersediaan anggaran, ketersediaan prosedur pengumpulan dan pendistribusian zakat, kriteria penerima zakat, dan umpan balik pembayar zakat serta penerima zakat

b. Tidak memenuhi pada kriteria muzakki

3. Berdasarkan indikator output pada zakat performace indicator, LAZNAS Al-Azhar :

a. Memenuhi pada kriteria jenis paket distribusi zakat, kepuasan akan realisasi pengumpulan zakat, persentase jumlah zakat yang terdistribusi, kepuasan akan realisasi jumlah zakat yang terdistribusi, peran paket distribusi zakat dalam menyelesaikan masalah mustahik atau meningkatkan taraf hidup mustahik, dan jumlah mustahik yang keluar dari kriteria mustahik setelah menerima paket distribusi zakat

b. Tidak memenuhi pada realisasi penerimaan dengan target penerimaan zakat
4. Berdasarkan indikator quality pada zakat performace indicator, LAZNAS Al-Azhar memenuhi pada status dana pengumpulan, ketersediaan sistem akuntansi dalam pengelolaan dana zakat, dan ketersediaan lembaga audit independen dalam melakukan audit terhadap laporan tahunan

5. Kesenjangan antara penerimaan dan penyaluran dana ZIS disebabkan oleh beberapa perusahaan yang berkomitmen untuk memberi donasi mencairkan dananya tidak pada tahun yang sama, beberapa perusahaan mencairkan dananya pada saat program sudah berjalan selama periode waktu tertentu dan setelah mendapat laporan progress program.

6. Dampak yang ditimbulkan dari kesenjangan tersebut yaitu LAZNAS Al-Azhar menggunakandana talangan terlebih dahulu dengan tujuan untuk mensukseskan program-program yang mereka miliki.

7. LAZNAS Al-Azhar telah berusaha untuk memberikan hasil yang terbaik kepada mustahik dan tidak mengecewakan muzakki yang telah mempercayai LAZNAS AlAzhar sebagai lembaga amil dalam melakukan pengelolaan dana ZIS, terlepas dari faktor-faktor yang kurang mendukung serta 
Ratnasari, et al: Jurnal Ekonomi Syariah Teori dan Terapan Vol. 6 No. 3 Maret 2019: 489-509; DAMPAK KESENJANGAN ANTARA PENERIMAAN DAN PENYALURAN DANA ZIS TERHADAP PROGRAM-PROGRAM LAZNAS AL-AZHAR

kesenjangan yang timbul dalam pengelolaan dana ZIS tersebut.

\section{DAFTAR PUSTAKA}

Afifuddin dan Beni Ahmad Saebani. 2012. Metodologi Penelitian Kualitatif. Bandung : CV Pustaka Setia.

Ali, Mohammad Daud. 1988. Sistem Ekonomi Islam: Zakat dan Wakaf. Jakarta : Universitas Indonesia

Al-Ba'ly, Abdul Al Hamid Mahmud. 2006.

Ekonomi Zakat: Sebuah Kajian Moneter dan Kevangan Syariah. Jakarta : Raja Grafindo Persada.

Al-Zuhayly, Wahbah. 1995. Zakat Kajian Berbagai Mazhab. Bandung: PT Remaja Rosdakarya

Arikunto, Suharsimi. 2006. Prosedur Penelitian. Jakarta: PT Rineka Cipta.

Ash-Shawi, Shalah dan Abdullah AlMushlih. 2015. Fikih Ekonomi Islam. Darul Haq : Jakarta

Aswayni, Qalbie Rianta. 2017. Analisis Ketidakefektifan Distribusi Dana Zakat di Kabupaten Sidoarja. (Studi kasus : BAZNAS Kabupaten Sidoarjo dan LAZNAS YDSF Kabupaten Sidoarjo.). Skripsi Sarjana Ekonomi Universitas Airlangga Surabaya

Azis, dkk. 2017. Zakat \& Pemberdayaan. Surabaya: Pusat Penerbitan dan Percetakan Universitas Airlangga.

Basri, Hasan. 2010. Manajemen Zakat: Menuju ke Arah Profesionalisasi. (Online),(http://kanazakat.blogspo t.com/2011/07/manajemenzakat.html, Diakses 21 Oktober 2018)
BAZNAS, 2016. Outlook Zakat Indoneisa 2017. Jakarta 2015. Outlook Zakat Indoneisa 2016. Jakarta

Beik, Irfan Syauqi. 2008. Pro Ekonomi Syariah Pro Rakyat. Jakarta: Republika

Bungin, Burhan. 2008. Analisis Data Penelitian Kualitatif Pemahaman Filosofis dan Metodologis ke Arah Penguasaan Model Aplikasi. Jakarta : Raja Grafindo Persada.

Chaudry, Muhammad Syarif. 2014. Sistem Ekonomi Islam Prinsip Dasar. Jakarta: Kencana Prenadamedia Group

Djuanda, Gustian dkk. 2006. Pelaporan Zakat Pengurang Pajak Penghasilan. Jakarta: Raja Grafindo Persada.

Fauzia, Amelia. 20013. Faith and The State: a History of Islamic Philantrophy in Indonesia. Leiden: Brill Academic Publishers. hlm. 175

Hafidhuddin, Didin. 2002. Zakat Dalam Perekonomian Modern. Jakarta: Gema Insani

Halim, Abd, dkk. 2011. Zakat Collection Distribution Gap: A measure of Effectiveness in The Management of Zakat. Makalah disajikan dalam Seminar Zakat Internasional, Bogor, 19-21 Juli 2011

Halim, Abd, dkk. 2015. "Efficiency of Islamic Institutions: Empirical Evidence of Zakat Organizations' Performance in Malaysia". Journal 
Ratnasari, et al: Jurnal Ekonomi Syariah Teori dan Terapan Vol. 6 No. 3 Maret 2019: 489-509; DAMPAK KESENJANGAN ANTARA PENERIMAAN DAN PENYALURAN DANA ZIS TERHADAP PROGRAM-PROGRAM LAZNAS AL-AZHAR

of Economics, Business and Management, Vol. 3, No. 2.

Hasan, M. Ali. 1996. Zakat, Pajak Asuransi dan Lembaga Keuangan. Jakarta: Raja Grafindo Persada.

Huda, Nurul dan Novarini. 2015. Zakat Perspektif Mikro-Makro Pendekatan Riset. Jakarta: Kencana Prenadamedia Group.

http://baznas.go.id/, diakses pada tanggal 20 Mei 2018

Inayah, Gazi. 2003. Teori Komprehensip Tentang Zakat dan Pajak. Yogyakarta: Tiara Wacana Yogya.

Indriyanti, Amanda Nuri. 2016. Analisis Overlapping (Tumpang Tindih) Distirbusi Zakat Pada LAZ di Surabaya. Skripsi Sarjana Ekonomi Universitas Airlangga Surabaya

Mahfud, Rois. 20011. Al-Islam: Pendidikan Agama Islam. Jakarta: Penerbit Erlangga

Moleong, Lexy J. 2001. Metode Penelitian Kualitatif Edisi Revisi. Bandung: Remaja Rosda Karya

Mufraini, Arif. 2006. Akuntansi dan Manajemen Zakat: Mengomunikasikan kesadaran dan Membangun Jaringan. Jakarta : Kencana Prenada media Group

Nasution, Mustafa Edwin dkk. 2015. Pengenalan Eksklusif Ekonomi Islam. Jakarta: Kencana Prenadamedia Group

Qardhawi, Yusuf. 1999. Hukum Zakat. Bandung: Pustaka Mizan.
. 2010. Shadaqah Cara Islam Mengentaslan Kemiskinan. Bandung: PT Remaja Rosdakarya Rozalinda. 2015. Ekonomi Islam Teori dan Aplikasinya pada Aktivitas Ekonomi. Jakarta: Raja Grafindo Persada.

Ryandono, Muhammad Nafik Hadi. 2008. Ekonomi ZISWAQ (Zakat, Infiaq, Shadaqah, dan Wakaf). Surabaya: IFDI dan Cenforis

Sari, Dian Permata. 2012. Penyebab Kesenjangan Antara Pengumpulan dan Pendistribusian Dana Zakat pada Rumah Cabang Zakat Surabaya. Skripsi Sarjana Ekonomi Universitas Airlangga Surabaya

Shihab, Quraish. 2001. Tafsir Al-Mishbah jilid 15. Tangerang Selatan : Lentera Hati.

Sudirman. 2007. Zakat dalam Pusaran Arus Modernitas. Malang: UIN-Malang Press.

Sugiyono. 2015. Metode Penelitian Kuantitatif Kualitatif dan R\&D. Bandung: Alfabeta

Sulistyo-Basuki. 2006. Metode Penelitian. Jakarta: Wedatama Widya Sastra dan Fakultas IImu Pengetahuan Budaya Universitas Indonesia

Syamil Al-Quran Miracle The Reference. 2010. Bandung: Sygma Publishing.

Ibnu Katsir, Tafsir Qur'an, 2015. hlm 5

Ritonga, A. Rahman dan Zainuddin MA. 1997. Fiqih Ibadah. Jakarta:Radar Jaya Pratama.

Shihab, Al-Misbah. Tafsir Qu'ran. 2009. HIm 350 
Tim Divisi Kepatuhan dan Kajian Dampak LAZ Al-Azhar. 2017. Panduan Zakat Lembaga Amil Zakat Al-Azhar. Jakarta : Lembaga Amil Zakat Nasional Al-Azhar.

Undang-Undang Republik Indonesia No. 23 Tahun 2011 Tentang Pengelolaan Zakat.

Widiastuti, Tika dan Suherman Rosyidi.

2015. Model dalam pendayagunaan zakat produktif oleh lembaga zakat dalam meningkatkan pendapatan mustahiq. Surabaya: Universitas Airlangga

Yin, Robert K. 2002. Studi Kasus Desain dan Metode. Jakarta: PT. Raja Grafindo Persada

Yin, Robert K. 2009. Studi Kasus, Desain dan Metode Ed 1. Jakarta: Rajawali Press.

www.alazharpeduli.org, diakses tanggal 2 Februari 2018

www.dompetdhuafa.org diakses tanggal 4 Mei 2018 www.republika.co.id diakses tanggal 28 Mei 2018 ww.pusat.baznas.go.id diakses tanggal 28 Mei 2018. 